\title{
PENGARUH KOORDINASI TERHADAP KINERJA DENGAN KEPUASAN SEBAGAI VARIABEL INTERVENING (The Effect of Coordination on Performance With Satisfaction as Intervening Variable)

\author{
Marsinta Uli Nainggolan'), Johannes ${ }^{2)}$, Sry Rosita ${ }^{2)}$ \\ ${ }^{1)}$ Staf pada Kantor Wilayah BPN Provinsi Jambi \\ 2) Program Magister Manajemen, Fakultas Ekonomi dan Bisnis, Universitas Jambi \\ Corresponding author: nainggolansinta1970@gmail.com
}

\begin{abstract}
Abstrak
Penelitian ini bertujuan untuk mengetahui dan menganalisis pengaruh koordinasi terhadap kinerja dengan kepuasan sebagai intervening pada Kantor Pertanahan Kota Jambi (KPKJ). Penelitian dilakukan dengan rancangan penelitian survey terhadap 80 orang pegawai di KPKJ dengan menggunakan jenis data melalui pendekatan kuantitatif, dan dengan alat analisis SmartPLS 3.0. Berdasarkan hasil penelitian menunjukkan bahwa koordinasi secara parsial dapat mempengaruhi kepuasan maupun kinerja pegawai KPKJ. Ini artinya jika koordinasi kerja meningkat maka kepuasan maupun kinerja pegawai KPKJ juga meningkat. Namun kepuasan secara parsial tidak mempengaruhi kinerja pegawai KPKJ, sehingga diartikan bahwa peningkatan kepuasan kerja pegawai tidak mempengaruhi peningkatan kinerja KPKJ. Demikian pula koordinasi melalui kepuasan tidak mempengaruhi kinerja pegawai, yang berarti bahwa kepuasan kerja pegawai tidak memiliki peran dalam memediasi koordinasi dan kinerja pegawai KPKJ. Berdasarkan hasil penelitian disarankan agar pegawai KPKJ tetap membangun kebiasaan kerja melalui koordinasi kerja mengingat perannya yang signifikan.
\end{abstract}

Kata kunci : Koordinasi, Kepuasan, Kinerja.

\section{Abstract}

This study aims to determine and analyze the effect of coordination on performance with satisfaction as an intervening at the Jambi City Land Office (KPKJ). The study was conducted with a survey research design of 80 employees at KPKJ using data types through a quantitative approach, and with the SmartPLS 3.0 analysis tool. Based on the results of the study indicate that coordination can partially affect the satisfaction and performance of KPKJ employees. This means that if work coordination increases, the satisfaction and performance of KPKJ employees will also increase. However, partial satisfaction does not affect the performance of KPKJ employees, so it means that increasing employee job satisfaction does not affect the performance of KPKJ employees. Likewise, coordination through satisfaction does not affect employee performance, which means that employee job satisfaction does not have a role in mediating the coordination and performance of KPKJ employees. Based on the results, we suggest that KPKJ employees continue building work coordination habits to affect performance enormously.

Keywords: Coordination, Satisfaction, Performance.

\section{PENDAHULUAN}

Organisasi pemerintah dituntut untuk selalu dapat merespon perubahan yang terjadi di masyarakat agar keberadaannya mampu terus menyesuaikan dengan kebutuhan masyarakat dan memberikan pelayanan yang prima konsep good governance yang dapat diartikan sebagai implementasi kebijakan tata kelola dan pelayanan yang tanggap terhadap kebutuhan masyarakat diterapkan secara efektif pada kantor pemerintahan. 
Sumber daya manusia sebagai pelaksana berbagai kegiatan dalam suatu organisasi dan memiliki peran yang sangat penting bagi keefektifan berjalannya kegiatan di dalam organisasi. Sebuah organisasi dituntut untuk mampu meningkatkan kualitas sumber daya manusia yang ada, karena sumber daya manusia memiliki peran yang sangat penting bagi keefektifan berjalannya kegiatan di dalam organisasi (Warr dan Nielsen, 2018).

Burton dan Obel (2018) mengemukakan bahwa dalam sebuah desain organisasi, kesesuaian antara struktur pembagian tugas dalam organisasi dengan koordinasinya harus ditentukan sebelumnya, atau bagaimana membuat tugas-tugas ini berjalan bersama sehingga dapat mewujudkan kinerja organisasi yang diharapkan. Kinerja organisasi dipandang sebagai kemampuan organisasi untuk mencapai tujuannya melalui penggunaan sumber daya dengan cara yang terstruktur dengan baik (Maduenyi et al., 2015).

Koordinasi sangat diperlukan untuk menciptakan terjadinya keselarasan antara tugas dan pekerjaan yang dilakukan oleh seseorang atau bagian yang satu dengan bagian yang lain. Untuk itu pada setiap bagian atau level jabatan hendaknya diperlengkapi dengan deskripsi pekerjaan (job description) pegawai yang jelas dan berkaitan dengan wewenang maupun tanggung jawab sesuai standar organisasi. Dengan adanya deskripsi pekerjaan akan memudahkan proses koordinasi antara anggota organisasi yang menciptakan keselarasan kerja sehingga tidak terjadi kesimpang siuran dan tumpang tindih pekerjaan. Sebagaimana hasil penelitian Alaloul et al., (2016) yang menyebutkan bahwa koordinasi dapat meningkatkan kinerja proyek. Demikian juga Tellioğlu (2010); (Han et al., 2017); Nawata et al., (2020) dalam hasil penelitiannya menunjukkan bahwa koordinasi merupakan hal penting dalam mengukur kerja tim atau memiliki pengaruh yang signifikan terhadap kinerja pegawai. Namun hasil penelitian tersebut berbeda dengan hasil penelitian (Fitriana, 2013) yang menunjukkan bahwa koordinasi secara parsial tidak berpengaruh signifikan terhadap kinerja pegawai.

Kepuasan kerja telah didefinisikan oleh para peneliti sebagai hal yang penting untuk kinerja organisasi. Kepuasan kerja dan prestasi kerja merupakan faktor penting utama yang harus dipertimbangkan manajemen dalam proses pengambilan keputusan manajerial untuk mengarahkan organisasi menuju tujuannya. Oleh karena itu, sangat penting untuk mengetahui faktor-faktor yang dapat mempengaruhi tingkat kepuasan kerja karyawan mereka karena hal itu akan mempengaruhi kinerja organisasi juga (Gangai dan Agrawal, 2015; Warr dan Nielsen, 2018). Penelitian Muhammad Arifin (2015); Pham (2016); Tenney et al., (2016); Tabassum et al., (2016); dan Muazza dan Syarifuddin H (2017) yang menunjukkan hasil bahwa kepuasan kerja berpengaruh positif dan signifikan terhadap kinerja pegawai baik secara individu maupun kolektif diantara karyawan. Artinya, semakin banyak orang yang puas dalam pekerjaan karyawan itu akan memberikan hasil yang baik. Karyawan dengan kepuasan kerja yang tinggi menunjukkan tingkat ketidakhadiran yang rendah, memiliki kontribusi positif tambahan untuk organisasi, dan sangat bersedia untuk terus melayani organisasi (Zhou et al., 2017). Hasil penelitian tersebut berbeda dengan penelitian Risqi et al., (2015); Tabassum et al., (2016); Pawirosumarto et al., (2017); serta Rosita dan Musnaini (2020) dan Pawirosumarto et al., (2017) yang menunjukkan hasil bahwa kepuasan kerja tidak berpengaruh secara positif sangat signifikan terhadap kinerja, artinya tingkat kinerja karyawan tidak ditentukan oleh tingkat kepuasan karyawan terhadap organisasi.

Kepuasan kerja diyakini dapat memediasi hubungan antara koordinasi dengan kinerja karyawan. Kepuasan kerja yang mengacu pada sikap umum karyawan merupakan persepsi karyawan mengenai seberapa baik pekerjaan mereka memberikan hal yang dinilai penting. Kepuasan kerja karyawan akan mendorong interaksi antara karyawan semakin baik, 
karyawan memiliki rasa kepercayaan yang tinggi terhadap rekan kerjanya; bahkan hubungan komunikasi sebagai salah satu upaya koordinasi kerja antara atasan dengan bawahan maupun sesama rekan kerja akan semakin mudah, selanjutnya diharapkan akan mewujudkan pencapaian kinerja organisasi. Hal ini ditunjukkan dengan penelitian Inuwa (2016) bahwa kepuasan kerja karyawan merupakan salah satu dinamika penting yang dapat menggambarkan hubungan rasa puas dengan rekan kerja maupun ada tidaknya dukungan atasan atas pekerjaan mereka.

KPKJ merupakan salah satu instansi vertikal Kementerian Agraria dan Tata Ruang/Badan Pertanahan Nasional di Kota Jambi yang mempunyai tugas menyelenggarakan urusan di bidang pertanahan dan tata ruang dalam pemerintahan. KPKJ sebagai instansi publik dalam menampilkan kinerja pelayanan publik yang tinggi untuk melaksanakan tugas dan fungsinya tentu saja harus didukung oleh sumber daya manusia untuk mencapai keunggulan kompetitif. Tugas dan fungsi KPKJ mengacu pada Peraturan Menteri Agraria dan Tata Ruang/Kepala Badan Pertanahan Nasional Republik Indonesia Nomor 38 Tahun 2016 tentang Organisasi dan Tata Kerja Kantor Wilayah Badan Pertanahan Nasional dan Kantor Pertanahan.

Sebagai instansi Pemerintah yang melayani masyarakat di bidang pertanahan, KPKJ memiliki beban pekerjaan yang semakin meningkat sepanjang tahun. Hal ini tentu membutuhkan adanya kekompakan, kerjasama dan sinergisitas antara SDM yang ada pada satu bagian (seksi) dengan bagian lainnya. Kenyataannya masalah koordinasi kerja sebagai salah satu faktor pembentuk hubungan kerja yang harmonis antara seksi / bagian masih dirasakan kurang, terlihat dalam pencapaian target kerja organisasi yang belum maksimal. Kemungkinan hal tersebut dikarenakan masih adanya egosentris dari setiap seksi, dimana masih mementingkan pekerjaannya masing-masing tanpa memperhatikan tujuan secara kolektifitas dari organisasi/instansi.

Masalah utama dalam penelitian adalah adanya dorongan keingintahuan peneliti terhadap kondisi kinerja pegawai KPKJ. Penelitian ini diharapkan dapat menjawab keingintahuan peneliti disamping peneliti ingin membuktikan beberapa teori yang telah dipelajari. Adanya faktor kepuasan kerja diharapkan akan dapat memediasi hubungan koordinasi antar pegawai maupun dengan atasannya, sebagai upaya peningkatan kinerja organisasi pada KPKJ.

\section{TINJAUAN PUSTAKA}

Begum dan Momen (2019) mendefenisikan koordinasi sebagai penyelarasan yang bertujuan dari unit, peran, tanggung jawab, dan upaya menyesuaikan tindakan dan keputusan organisasi untuk mencapai tujuan bersama yang ditargetkan. Koordinasi adalah masalah utama untuk keefektifan organisasi mana pun, yang diperlukan di semua tahap kebijakan publik atau aktivitas dalam organisasi.

Alaloul et al., (2016) juga mendefenisikan koordinasi sebagai proses mengelola ketergantungan di antara kegiatan dan menghubungkan bersama-sama bagian yang berbeda untuk menyelesaikan serangkaian tugas bersama. Koordinasi merupakan proses berulang untuk membangun kepercayaan secara bertahap, memahami dan menjalin hubungan kerja, menyiapkan semua elemen agar kru dapat melakukan pekerjaan secara efektif dan efisien sejak pertama kali. Selanjutnya tujuan dari proses koordinasi adalah untuk mengurangi kelambatan informasi melalui sinkronisasi dan integrasi kegiatan dan tanggung jawab untuk memastikan bahwa sumber daya digunakan paling efisien untuk mencapai tujuan yang telah ditetapkan. 
Proses koordinasi mengacu pada kegiatan yang mengatur urutan dan waktu pekerjaan yang saling bergantung, seperti mengatur pekerjaan, menugaskan pekerjaan kepada anggota tim, dan menjelaskan aturan dan prosedur standar. Proses koordinasi memerlukan komunikasi anggota tim untuk mengartikulasikan rencana, menentukan tanggung jawab, menegosiasikan tenggat waktu, dan mencari informasi untuk melakukan tugas-tugas umum (Han et al., 2017).

Koordinasi dalam konteks antar organisasi sektor publik dianggap sebagai instrumen dan mekanisme yang bertujuan untuk meningkatkan penyelarasan sukarela atau paksa tugas dan upaya organisasi dalam sektor publik. Koordinasi memerlukan beberapa fleksibilitas dan beberapa kemauan untuk berpikir tentang kebijakan dan administrasi dengan cara yang kurang konvensional, dan karenanya individu dan organisasi yang beroperasi dalam stereotip, cara bergantung jalan yang biasanya dianggap berasal dari 'birokrasi' mungkin tidak bersedia untuk menjauh dari pola yang ada (Bouckaert et al., 2010). Pengukuran koordinasi menurut Vanagas dan Stankevič (2015) meliputi : pembagian kerja, mencakup pendelegasian wewenang dan spesialisasi; perbedaan sikap, individu antara karyawan yang menghambat untuk menemukan solusi yang sesuai, metode kerja, gaya, atau waktu; hubungan staf, jika komunikasi antara karyawan dan manajer tidak efektif, komunikasi tidak memadai, tidak ada umpan balik atau konflik nonkonstruktif; masalah alokasi sumber daya yang terbatas, dimana ketika departemen yang berbeda harus berbagi sumber daya yang sama pada waktu yang sama atau pada gilirannya untuk memanfaatkannya secara lebih efektif. Penggunaan pengukuran tersebut secara efektif dalam manajemen organisasi mengarah ke hasil yang lebih baik.

Selanjutnya Tellioğlu (2010) mengemukakan dampak utama terkait kegiatan koordinasi yaitu : adanya saling ketergantungan antara tugas, definisi sukses, dan mekanisme koordinasi. Untuk menciptakan koordinasi yang efektif diperlukan komunikasi dan hubungan kerja. Dimana koordinasi mengacu pada pembentukan saluran komunikasi antara orang-orang yang melaksanakan pekerjaan yang berbeda. Koordinasi melalui proses komunikasi, interaksi sosial dan hubungan kerja, karyawan dapat mengekspresikan emosi kekecewaan atau kepuasan satu sama lain dan dengan manajemen mereka, sehingga hal ini menunjukkan pula bahwa pada kenyataannya terdapat hubungan keterkaitan antara koordinasi dengan kepuasan kerja ( Alsayed et al., 2012).

Cantarelli et al. (2013) menggambarkan kepuasan kerja sebagai perasaan seorang pekerja tentang pekerjaannya atau sebagai keadaan emosional yang menyenangkan atau positif, yang dihasilkan dari penilaian pekerjaan atau pengalaman kerja seseorang. Selanjutnya kepuasan kerja menurut Robbins dan Judge (2015) serta Nurcahyani dan Adnyani (2016) yaitu dipenuhinya keinginan dan kebutuhannya melalui kegiatan bekerja. Selain itu kepuasan kerja juga dapat diartikan sebagai penilaian, perasaan atau sikap seseorang atau pegawai terhadap pekerjaannya dan berhubungan dengan lingkungan kerja, jenis pekerjaan, kompensasi, hubungan antar rekan kerja, hubungan sosial ditempat kerja dan sebagainya. Di sisi lain, kepuasan karyawan berkorelasi positif dengan motivasi, keterlibatan kerja, komitmen organisasi, kepuasan hidup, kesehatan mental dan prestasi kerja dan berhubungan negatif dengan ketidakhadiran, pergantian dan stress yang dirasakan dan mengidentifikasinya sebagai sejauh mana seseorang merasa puas dengan pekerjaannya (Shaukat et al., 2015).

Lima dimensi kepuasan menurut Rosita dan Musnaini (2020) yaitu : pemenuhan kebutuhan, merupakan karakteristik pekerjaan yang memungkinkan adanya kesempatan bagi individu untuk memenuhi kebutuhannya; perbedaan adalah hasil yang memenuhi harapan; pencapaian nilai, adalah persepsi pekerjaan yang memberikan pemenuhan nilai- 
nilai penting pekerjaan individu; keadilan, adalah bagaimana individu diperlakukan secara adil di tempat kerja; komponen dispotional / genetik, adalah fungsi dari ciri-ciri pribadi dan faktor genetik.

Inuwa (2016) menyebutkan beberapa elemen yang menentukan kepuasan kerja di tempat kerja yang meliputi paket keuangan seperti gaji, peluang, kemajuan, kondisi kerja, dan kelompok kerja, selanjutnya efek yang dihasilkan dari determinan tersebut berfungsi sebagai tolak ukur kepuasan kerja. Kepuasan kerja karyawan dapat dianggap sebagai tujuan terpenting bagi organisasi mana pun karena terkait dengan produktivitas karyawan secara keseluruhan, retensi karyawan, profitabilitas organisasi dan kepuasan pelanggan. Departemen SDM organisasi mana pun dianggap bertanggung jawab untuk menciptakan kepuasan kerja di antara karyawan organisasi mana pun sehingga mereka tidak hanya dapat melakukan tugas pekerjaan rutinnya dengan cermat tetapi juga harus dapat berkontribusi dalam pemenuhan tujuan organisasi secara keseluruhan (Khan et al., 2015).

Menurut model karakteristik pekerjaan kepuasan kerja dan studi sejarah, pekerja cenderung lebih puas dengan pekerjaan mereka dalam tiga kondisi yaitu : a) ketika mereka mengalami pekerjaan mereka sebagai sesuatu yang berarti, b) ketika mereka mengalami tanggung jawab atas hasil pekerjaan dan c) ketika mereka memiliki pengetahuan tentang hasil pekerjaan mereka (Pham, 2016).

Lebih lanjut Tabassum et al., (2016) mengidentifikasi berbagai faktor yang menentukan kepuasan kerja, yaitu gaji, promosi, supervisi, tunjangan, penghargaan, prosedur pelaksanaan, rekan kerja, sifat pekerjaan, komunikasi. Dari semua ciri seorang karyawan, kepuasan kerja organisasi adalah salah satu yang telah dipelajari dan diperdebatkan paling mempertimbangkan pengaruhnya pada banyak area lain organisasi serta pengaruhnya terhadap kinerja karyawan, niat berpindah dan lain-lain (Khan et al., 2015). Karyawan yang memiliki tingkat kepuasan yang tinggi dalam pekerjaannya akan tampak lebih tenang, profesional, dan seimbang dengan pelanggan yang memberikan citra positif keseluruhan organisasi. Padahal sebaliknya, staf yang memiliki tingkat kepuasan kerja yang lebih rendah akan berperilaku tidak menyenangkan dan tidak profesional sehingga menimbulkan kesan negatif bagi organisasi secara keseluruhan dan pada akhirnya tidak berpihak pada pencapaian tujuan kinerja organisasi (Tenney et al., 2016).

Kinerja pada dasarnya adalah apa yang dilakukan atau tidak dilakukan oleh karyawan; kinerja karyawan mempengaruhi seberapa besar kontribusi mereka kepada organisasi yang meliputi kuantitas output, kualitas output, kehadiran kerja dan sikap kooperatif. Dengan demikian kinerja akan menurun jika salah satu faktor berkurang atau tidak ada (Pawirosumarto et al., 2017) sebagaimana Berman (2006) dalam bukunya juga menyebutkan bahwa kinerja sebagai penggunaan sumber daya yang efektif dan efisien sebuntuk mencapai hasil.

Pradhan dan Jena (2017) mengemukakan tiga dimensi dalam pengukuran kinerja karyawan yaitu : kinerja tugas, meliputi pengetahuan atau prinsip teknis yang diperlukan untuk memastikan kinerja pekerjaan dan memiliki kemampuan untuk menangani banyak tugas; kinerja adaptif, kemampuan karyawan untuk secara efisien menangani keadaan kerja yang tidak stabil, karyawan dapat menyesuaikan perilaku interpersonalnya sedemikian rupa mengubah keadaan agar berhasil bekerja dengan berbagai rekan dan bawahan, menciptakan tempat kerja yang lebih baik; kinerja kontekstual, semangat tim, menjunjung tinggi antusiasme di tempat kerja, bekerja sama dengan orang lain pada saat dibutuhkan, berbagi sumber daya dan informasi penting untuk pengembangan organisasi, mematuhi aturan dan peraturan yang ditentukan, dan mendukung keputusan organisasi untuk perubahan yang lebih baik. 
Kinerja pekerjaan individu harus didefinisikan seperti hal-hal yang sebenarnya dilakukan orang, tindakan yang mereka ambil, yang berkontribusi pada tujuan organisasi. Seseorang harus mengidentifikasi tindakan yang relevan dengan tujuan organisasi dan yang tidak, terlepas dari apakah tindakan tersebut ada dalam deskripsi pekerjaan tertulis. Bagi mereka yang relevan, tingkat kemahiran individu dalam melaksanakannya harus diskalakan (Campbell dan Wiernik, 2015). Selanjutnya Hery (2019) dan Bakotić (2016) menyebutkan bahwa pelaksanaan kinerja dipengaruhi oleh beberapa faktor internal maupun eksternal. Selanjutnya penelitian Klein dan Francisco (2012) mengemukakan empat karakter yang dapat digunakan pimpinan dalam mengevaluasi kinerja yaitu : fokus kepemimpinan, keterlibatan karyawan, praktik sesuai dengan prosedur, rumah tangga yang sangat baik.

\section{METODE PENELITIAN}

\section{Populasi dan Sampel}

Populasi penelitian adalah pegawai Kantor Pertanahan Kota Jambi. Teknik pengambilan sampel adalah metode acak, ukuran sampel yang diambil yaitu sebanyak 80 orang responden.

\section{Sumber Data}

Data primer diperoleh melalui kuisioner yang dibagikan kepada responden dengan pernyataan tertutup, kuesioner dibagian melalui google formulir, sedangkan data sekunder diperoleh dari instansi yang dijadikan sampel.

\section{Analisis dan Alat Analisis Data}

Data menggunakan distribusi frekuensi untuk memperoleh nilai rata-rata, diolah menggunakan software Partial Least Square atau SmartPLS 3,0.

\section{Variabel Penelitian}

Variabel penelitian dan masing-masing indikatornya adalah sebagai berikut : koordinasi (X) : 1) pembagian kerja dan spesialisasi, 2) perbedaan sikap, 3) hubungan staf, 4) masalah alokasi sumber daya yang terbatas; kepuasan (Z) : 1) pemenuhan kebutuhan, 2) perbedaan, 3) pencapaian nilai, 4) keadilan, 5) komponen dispotional/genetic; dan kinerja (Y) : 1) kinerja tugas, 2) kinerja adaptif, 3) kinerja kontekstual.

\section{HASIL DAN PEMBAHASAN \\ Karakteristik Responden}

Responden berusia 25 sampai 30 tahun sebanyak 35 orang dengan jenis kelamin umumnya perempuan yaitu sebanyak 48 orang atau sebesar $60 \%$. Apabila dilihat dari segi pendidikan terakhir, tingkat pendidikan didominasi oleh pegawai dengan tingkat pendidikan S1 sebanyak 46 orang dan SMA/SMK sebanyak 26 orang. Karakteristik pekerjaan dengan jumlah ASN sebanyak 28 orang, PPNPM 45 orang, ASK 5 orang, Cleaning Service 1 orang dan Satpam sebanyak 1 orang dengan dominasi masa kerja di bawah 5 tahun yaitu sebanyak 31 orang atau sebesar 38,7\%.

\section{Nilai dan Rata-Rata Variabel Penelitian}

Penilaian responden terhadap masing-masing variabel penelitian, dimana variabel koordinasi pada dimensi perbedaan sikap memiliki nilai rata-rata tertinggi yaitu sebesar 4,11, selanjutnya variabel kinerja pada dimensi kontekstual sebesar 3,96, dan variabel kepuasan pada dimensi pencapaian nilai sebesar 3,91. 


\section{Model Pengukuran (Outer Model)}

Menurut Ghozali, I. dan Latan, H. (2015), untuk menilai validitas konvergen yaitu nilai loading factor harus lebih dari 0,70 dan Average Variance Extracted $\geq 0,50$, dimana dari pengolahan data ditemukan bahwa semua item dalam penelitian ini adalah valid.

Untuk menguji validitas diskriminan yaitu dengan melihat nilai cross loading untuk setiap variabel harus $>0,70$. Secara rinci dapat dilihat pada Tabel 1 berikut ini :

Tabel 1. Nilai Loading Factor \& AVE Koordinasi, Kepuasan dan Kinerja Kantor Pertanahan Kota Jambi

\begin{tabular}{cccc}
\hline Variabel & Indikator & Loading Factor & AVE \\
\hline Koordinasi & $\mathrm{X}_{1}$ & 0,802 & 0,720 \\
& $\mathrm{X}_{2}$ & 0,878 & \\
& $\mathrm{X}_{3}$ & 0,831 & \\
& $\mathrm{X}_{4}$ & 0,880 & 0,900 \\
Kinerja & $\mathrm{Y}_{1}$ & 0,950 & \\
& $\mathrm{Y}_{2}$ & 0,945 & 0,821 \\
& $\mathrm{Y}_{3}$ & 0,951 & \\
Kepuasan & $\mathrm{Z}_{1}$ & 0,898 & \\
& $\mathrm{Z}_{2}$ & 0,903 & \\
& $\mathrm{Z}_{3}$ & 0,894 & \\
& $\mathrm{Z}_{4}$ & 0,925 & \\
$\mathrm{Z}_{5}$ & 0,911 & \\
\end{tabular}

Sumber : Diolah untuk penelitian (2021).

Terlihat bahwa dari hasil output analisis semua konstruk menghasilkan nilai loading factor > 0,70 yang berarti memenuhi convergent validity (validitas konvergen) atau semua indikator konstruk adalah valid. Begitu juga pada uji validitas kedua yaitu validitas diskriminan, dimana nilai Average Variance Extracted (AVE) semua variabel $>0,50$, sehingga memenuhi persyaratan validitas konvergen dan reliabilitas seperti dapat dilihat pada Gambar 1 berikut ini :

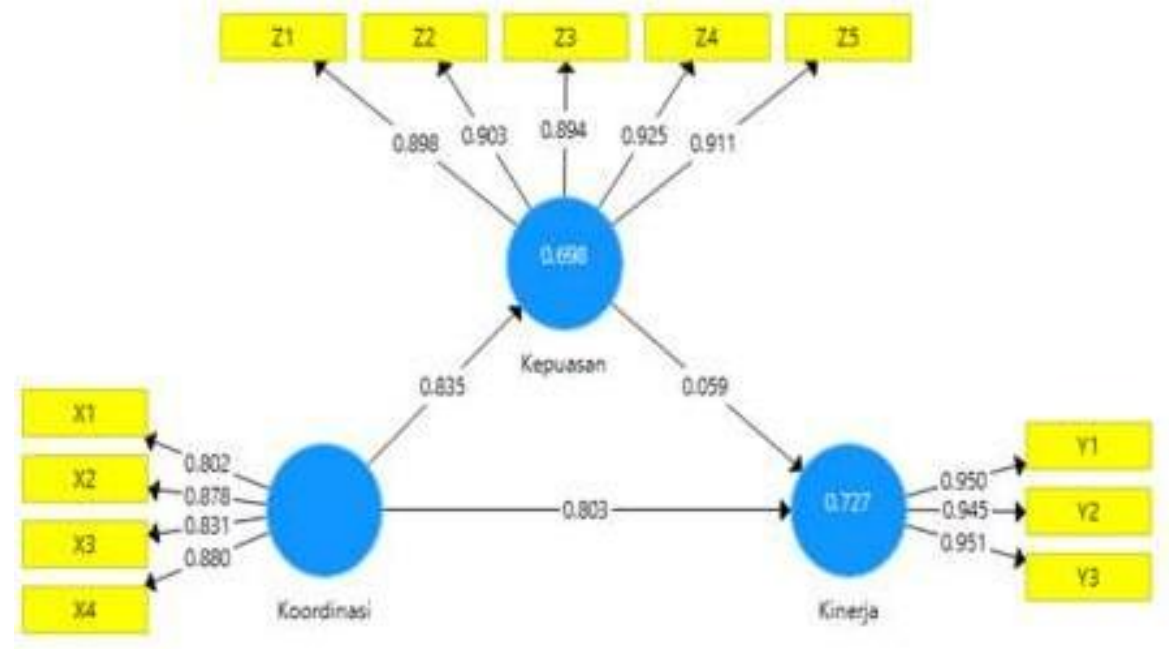

Gambar 1. Path Coefficients Koordinasi, Kepuasan dan Kinerja

Kantor Pertanahan Kota Jambi

Selain uji validitas, pengukuran model juga dilakukan untuk menguji reliabilitas suatu konstruk dengan cara Cronbach's Alpha dan Composite Reliability. Secara rinci dapat dilihat pada Tabel 2 berikut ini : 
Tabel 2. Nilai Cronbach's Alpha dan Composite Reliability Koordinasi, Kepuasan dan Kinerja Kantor Pertanahan Kota Jambi

\begin{tabular}{ccc}
\hline Variabel & Cronbach's Alpha & Composite Reliability \\
\hline Koordinasi & 0,946 & 0,958 \\
Kinerja & 0,944 & 0,964 \\
Kepuasan & 0,870 & 0,911 \\
\hline
\end{tabular}

Sumber : Diolah untuk penelitian (2021).

Nilai Cronbach's Alpha dan Composite Reliability yang dihasilkan semua konstruk sangat baik yaitu memiliki nilai > 0,70. Hal ini menandakan variabel-variabel yang diajukan adalah reliable atau memenuhi uji reliabilitas.

\section{Model Struktural (Inner Model)}

Berikut ini adalah hasil evaluasi inner model pada penelitian ini :

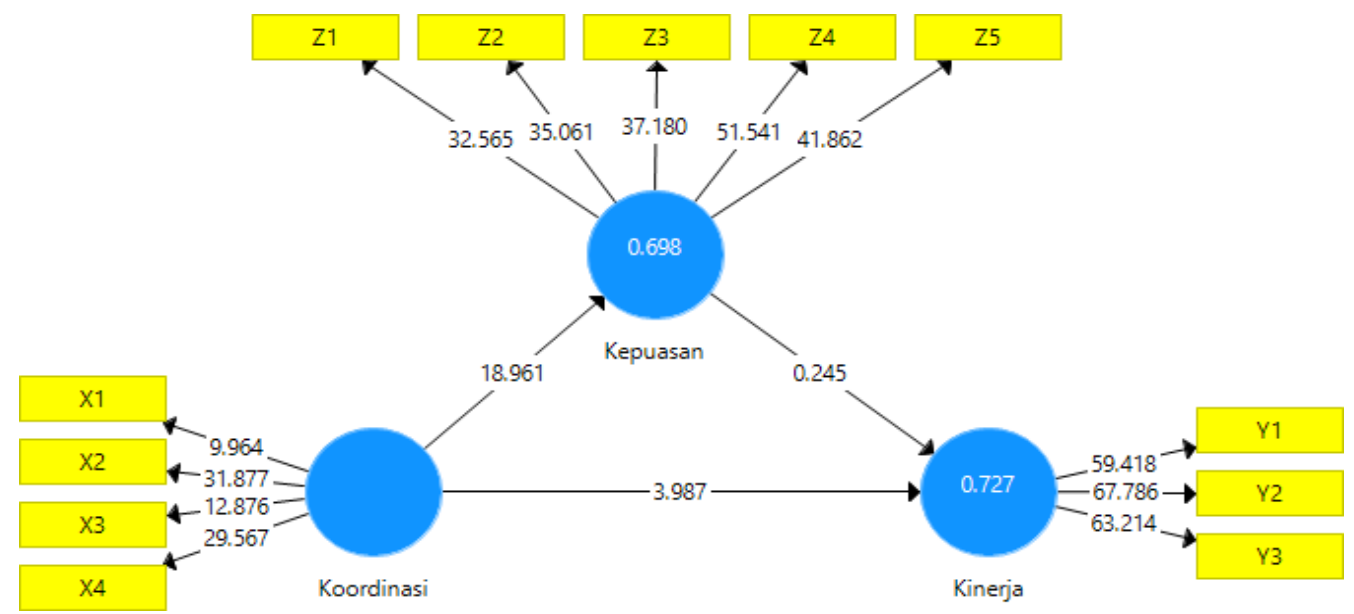

Gambar 1. Nilai T-Statistic Koordinasi, Kepuasan dan Kinerja Kantor Pertanahan Kota Jambi

Ada dua komponen dalam penelitian model struktural yaitu pengujian R-Squares $\left(\mathrm{R}^{2}\right)$, merupakan pengujian yang dilakukan dengan melihat nilai R-Squares yang merupakan uji goodness fit model, untuk setiap variabel laten endogen sebagai kekuatan prediksi dari model structural dan Signifikansi. Nilai R-Squares dari hasil analisis penelitian dapat dilihat pada Tabel 3 berikut ini :

Tabel 3. Nilai R-Squares Kepuasan dan Kinerja Kantor Pertanahan Kota Jambi

\begin{tabular}{cc}
\hline Variabel & R-Squares \\
\hline Kepuasan & 0,698 \\
Kinerja & 0,727 \\
\hline
\end{tabular}

Sumber : Diolah untuk penelitian (2021). 
Berdasarkan Tabel 3 dapat dilihat bahwa kepuasan kerja memiliki nilai 0,698 sedangkan nilai kinerja memiliki nilai 0,727 yang menandakan bahwa kedua variabel termasuk dalam kategori moderat. Hal ini juga dapat diartikan bahwa koordinasi memberikan sumbangan sebesar 69,8\% terhadap kepuasan kerja, sedangkan sisanya sebesar 30,2\% dipengaruhi oleh variabel lain. Kemudian koordinasi dan kepuasan kerja memberikan sumbangan sebesar $72,7 \%$ terhadap kinerja, sedangkan sisanya $27,3 \%$ dipengaruhi oleh variabel lain yang tidak diteliti dalam penelitian ini.

Hasil pengujian hipotesis baik secara langsung maupun tidak langsung dengan SmartPLS 3,0 yaitu suatu hubungan dikatakan signifikan jika nilai T Statistic $>1.960$ atau $\mathrm{P}$ Value $<0.05$. Secara rinci dapat dilihat pada Tabel 4 berikut ini.

Tabel 4. Uji Hipotesis Koordinasi, Kepuasan dan Kinerja

Kantor Pertanahan Kota Jambi

\begin{tabular}{|c|c|c|c|c|c|}
\hline Uji & Model & $\begin{array}{l}\text { Original } \\
\text { Sample }\end{array}$ & T Statistic & P Value & Keterangan \\
\hline \multirow[t]{6}{*}{ Pengaruh Langsung } & Koordinasi & 0,803 & 3,987 & 0.000 & Signifikan \\
\hline & Kinerja & & & & $\mathrm{H}_{1}$ : diterima \\
\hline & Koordinasi & 0,835 & 18,961 & 0,000 & Signifikan \\
\hline & Kepuasan & & & & $\mathrm{H}_{2}$ : diterima \\
\hline & Kepuasan & 0,059 & 0,245 & 0,806 & Tidak \\
\hline & Kinerja & & & & Signifikan \\
\hline Pengaruh & Koordinasi & 0,049 & 0,240 & 0,811 & $\begin{array}{c}\mathrm{H}_{3} \text { : ditolak } \\
\text { Tidak }\end{array}$ \\
\hline Tidak & Kepuasan & & & & Signifikan \\
\hline Langsung & Kinerja & & & & $\mathrm{H}_{4}$ : ditolak \\
\hline
\end{tabular}

Sumber : Diolah untuk penelitian (2021).

\section{Pembahasan}

Hasil pengujian menunjukkan bahwa terdapat pengaruh yang positif dan signifikan dari kordinasi terhadap kinerja KPKJ. Hal ini menunjukkan bahwa jika koordinasi kerja pegawai meningkat maka semakin meningkat pula kinerja KPKJ. Dimensi variabel yang paling berpengaruh untuk mengukur koordinasi kerja pegawai yaitu pada dimensi masalah alokasi sumber daya yang terbatas yang mengidentifikasi alasan bahwa karyawan (pegawai) ditempatkan untuk menangani pekerjaan sesuai dengan kemampuan, keahlian dan pendidikan yang dimiliki serta mampu menangani beban pekerjaan yang lebih besar. Hal ini sesuai dengan penjelasan Vanagas dan Stankevič (2015) yang mana dalam penelitiannya menyatakan bahwa semua karyawan harus mengembangkan kemampuan untuk mengoperasikan alur kerja dengan baik, sehingga memudahkan proses pembagian kerja maupun pada saat menjalankan tugas atau pekerjaan lain yang diberikan oleh atasan. Selanjutnya hasil pengujian ini juga mendukung penelitian Butchibabu et al., (2016) dan Han et al., (2017) yang juga meneliti variabel koordinasi terhadap kinerja karyawan dan memberikan hasil bahwa proses koordinasi secara positif memprediksi kinerja tim, demikian pula Begum dan Momen (2019) dalam penelitiannya bahwa koordinasi merupakan hal yang sangat penting untuk mempromosikan praktik tata kelola yang baik dan memastikan keberhasilan pelaksanaan proyek dan program pembangunan.

Berdasarkan hasil pengujian juga menunjukkan bahwa terdapat pengaruh yang positif dan signifikan dari kordinasi terhadap kepuasan kerja KPKJ. Hal ini menunjukkan bahwa jika koordinasi kerja pegawai meningkat maka semakin meningkat pula kepuasan kerja KPKJ. Dimensi variabel yang paling berpengaruh untuk mengukur kepuasan kerja yaitu pada dimensi keadilan, yang mengidentifikasi alasan bahwa dengan adanya koordinasi satu sama lain, karyawan (pegawai) merasa puas dengan perlakuan adil di tempat kerja 
dan merasa memiliki kesempatan yang sama untuk peningkatan karier atau untuk dipromosikan. Hasil pengujian ini mendukung penelitian terdahulu dari Phuong et al. (2018) yang menyatakan bahwa jika suatu perusahaan ingin mencapai prestasi kerja yang tinggi dan kepuasan kerja yang tinggi pada saat yang sama, maka perusahaan harus membangun lingkungan di mana terdapat koordinasi yang baik antar karyawan. Lebih lanjut Alsayed et al. (2012) juga dalam penelitiannya menyatakan bahwa komunikasi sebagai kunci dari koordinasi yang efektif dapat dicapai dengan adanya hubungan kerja yang efektif yang saling terkait satu sama lain. Ketika informasi mengalir dengan bebas di antara suatu organisasi, itu meningkatkan kepercayaan dan memastikan partisipasi bawahan dalam pengambilan keputusan. Komunikasi yang efektif lebih jauh, mengarah pada kepuasan komunikasi di antara anggota organisasi, selanjutnya berkontribusi untuk mencapai indikator kinerja yang diinginkan.

Berdasarkan hasil pengujian menunjukkan bahwa tidak terdapat pengaruh yang signifikan dari kepuasan kerja terhadap kinerja KPKJ. Hal ini mengidentifikasi alasan bahwa masing-masing dimensi variabel kepuasan yang diajukan tidak relevan untuk diterapkan sebagai model penelitian yang mengukur adanya pengaruh antara variabel koordinasi terhadap variabel kinerja pada KPKJ. Apabila dilihat dari beban pekerjaan yang besar setiap tahunnya, dimana jumlah pegawai yang bekerja lebih didominasi oleh pegawai PPNPM (Pegawai Pemerintah Non Pegawai Negeri), dapat dijadikan salah satu faktor penyebab tidak dapat terukurnya kepuasan kerja terhadap kinerja pegawai. Masalah kepuasan kerja menjadi terabaikan, manakala secara tidak langsung pegawai hanya dituntut untuk mencapai target pekerjaan tepat waktu. Sehingga kinerja pegawai hanya diukur berdasarkan bagaimana mereka dapat mencapai target pekerjaan di akhir tahun. Hasil pengujian ini menolak hasil penelitian terdahulu yang dilakukan oleh Adam dan Kamase (2019) serta Suyitno (2017) yang menyatakan bahwa kepuasan berpengaruh positif dan signifikan terhadap kinerja.

Pengujian hipotesis yang menunjukkan bahwa tidak terdapat pengaruh yang positif dan signifikan antara koordinasi terhadap kinerja melalui kepuasan kerja KPKJ. Dari hasil pengujian ini dapat disimpulkan bahwa semua dimensi variabel kepuasan yang diajukan dalam penelitian ini bukan merupakan variabel mediasi atau intervening yang relevan untuk diterapkan sebagai model penelitian yang mengukur pengaruh antara variabel koordinasi terhadap variabel kinerja pada KPKJ. Koordinasi merupakan hal yang penting dalam organisasi yang kompleks sebagaimana KPKJ, karena disitu terdapat banyak kegiatan yang berlainan dan dilakukan oleh banyak orang dalam banyak bagian. Dimensi kepuasan kerja pegawai seperti yang dijabarkan dalam kuesioner yang dibagikan tidak mengindikasikan sebagai alasan bagi pegawai untuk peningkatan kinerja organisasi. Hasil pengujian ini menolak hasil penelitian terdahulu yang dilakukan oleh Alsayed et al. (2012) yang menyatakan bahwa terdapat hubungan keterkaitan antara koordinasi dengan kepuasan kerja melalui ekspresi emosi kekecewaan atau kepuasan satu sama lain terhadap manajemen mereka; selanjutnya koordinasi melalui proses komunikasi, interaksi sosial dan hubungan kerja secara konsisten diidentifikasi dalam peningkatan kinerja tim.

\section{SIMPULAN DAN SARAN}

\section{Simpulan}

Berdasarkan hasil analisis penelitian dan hasil pembahasan, berikut beberapa kesimpulan yang dapat diambil :

1. Koordinasi memiliki pengaruh positip dan signifikan terhadap kinerja. Ini perlu diperkuat dengan penempatan pegawai yang sesuai terhadap kemampuan, keahlian dan pendidikan yang sesuai dengan SDM. 
2. Koordinasi memiliki pengaruh positip dan signifikan terhadap kepuasan. Apabila koordinasi kerja meningkat maka kepuasan kerja KPKJ juga akan meningkat. Hubungan yang baik antara atasan dan bawahan diantaranya melalui bentuk komunikasi yang efektif akan meningkatkan kepuasan kerja pegawai.

3. Kepuasan tidak memiliki pengaruh positip dan signifikan terhadap kinerja. Ini menunjukkan bahwa karyawan lebih berorientasi kepada tugas, dibanding dengan orientasi terhadap pemenuhan kebutuhan immaterialnya.

\section{Saran}

Agar pegawai KPKJ tetap membangun kebiasaan kerja melalui upaya koordinasi kerja yang baik antara satu dengan lainnya, mengingat faktor-faktor koordinasi dalam hasil pengujian terbukti berpengaruh dalam meningkatkan kepuasan kerja maupun kinerja pegawai.

Untuk keperluan akademik, kiranya perlu penelitian lebih lanjut dan menggunakan hasil penelitian ini sebagai bahan perbandingan maupun referensi untuk penelitian, dengan menggunakan variabel lain yang berbeda untuk dijadikan sebagai mediator dalam memediasi hubungan antara koordinasi dan kinerja.

\section{DAFTAR PUSTAKA}

Alaloul, W. S., Liew, M. S., \& Zawawi, N. A. W. A. (2016). Identification of coordination factors affecting building projects performance. Alexandria Engineering Journal, 55(3), 2689-2698. https://doi.org/10.1016/j.aej.2016.06.010

Alsayed, A. K., Motaghi, M. H., \& Osman, I. B. (2012). The relationship between communication satisfaction and performance indicators in Palestinian governmental organization. International Journal of Scientific and Research Publications, 2(11), 19. http://www.ijsrp.org/research-paper-1112/ijsrp-p1151.pdf

Bakotić, D. (2016). Relationship between job satisfaction and organisational performance. Economic Research-Ekonomska Istrazivanja , 29(1), 118-130. https://doi.org/10.1080/1331677X.2016.1163946

Begum, M. M., \& Momen, M. N. (2019). Coordination and Effective Governance. Global Encyclopedia of Public Administration, Public Policy, and Governance, 1-6. https://doi.org/10.1007/978-3-319-31816-5_2000-1

Bouckaert, G., Peters, B. G., \& Verhoest, K. (2010). The Coordination of Public Sector Organizations_Shifting Patterns of Public Management. Palgrave Macmillan.

Burton, R. M., \& Obel, B. (2018). The science of organizational design: fit between structure and coordination. Journal of Organization Design, 7(1). https://doi.org/10.1186/s41469-018-0029-2

Campbell, J. P., \& Wiernik, B. M. (2015). The Modeling and Assessment of Work Performance. In Annual Review of Organizational Psychology and Organizational Behavior (Vol. 2). https://doi.org/10.1146/annurev-orgpsych-032414-111427

Cantarelli, P., Belardinelli, P., \& Belle, N. (2013). A Meta-Analysis of Job Satisfaction Correlates in the Public Administration Literature. Review of Public Personnel Administration, 36(2), 115-144. https://doi.org/10.1177/0734371X15578534

Fitriana, W. (2013). Pengaruh Koordinasi, Pengawasan dan Iklim Kerja terhadap Kinerja Pegawai di Kantor Dinas Sosial Provinsi Jawa Barat. Empowerment, 2 No. 1(2252), 63-78.

Gangai, N., \& Agrawal, R. (2015). Job Satisfaction and Organizational Commitment: Is It important for Employee Performance. 5(4), 269-278. 
Ghozali, I., \& Latan, H. (2015). Partial Least Squares, Konsep, Teknik dan Aplikasi Menggunakan Program SmartPLS 3.0, Untuk Penelitian Empiris (Edisi 2). Universitas Diponegoro Semarang.

Halevy, N., Y. Chou, E., \& D. Galinsky, A. (2011). A functional model of hierarchy. Organizational Psychology Review, 1(1), 32-52. https://doi.org/10.1177/2041386610380991

Han, S. J., Lee, Y., Beyerlein, M., Kolb, J., \& Kolb, J. (2017). The role of coordination , goal commitment, and Knowledge Sharing on Perceived Team Performance. https://doi.org/10.1108/TPM-11-2016-0050

Hery. (2019). Manajemen Kinerja. PT. Grasindo.

Inuwa, M. (2016). Job Satisfaction and Employee Performance: An Empirical Approach. The Millennium University Journal, 1(1), 90-103.

Khan, I. U., Ahmed, K., Zulqarnain, W., \& Jamil, S. (2015). Impact of HR Competencies on Employee' s Job Satisfaction. 5, 15-28.

Klein, J. A., \& Francisco, E. M. (2012). Focus on Personal Operational Discipline to Get Work Done Right. https://doi.org/10.1002/prs.11488

Krejcie, R. V., \& Morgan, D. W. (1970). Determining Sample Size for Research Activities. Educational and Psychological Measurement, 30(3), 607-610. doi:10.1177/001316447003000308

Maduenyi, S., Oke, A. O., Fadeyi, O., \& Ajagbe, M. A. (2015). Paper 140.pdf. In International Conference on African Development Issues: Social and Economic Models for Development track (pp. 354-358).

Muazza, M., \& Syarifuddin H, B. (2017). Does Job Rotation and Job Satisfaction Affect the Performance? Journal of Business Studies and Mangement Review, 1(1), 1-4. https://doi.org/10.22437/jb.v1i1.3914

Muhammad Arifin, H. (2015). The influence of competence, motivation, and organisational culture to high school teacher job satisfaction and performance. International Education Studies. https://doi.org/10.5539/ies.v8n1p38

Nawata, K., Yamaguchi, H., \& Aoshima, M. (2020). Team implicit coordination based on transactive memory systems. 26(7), 375-390. https://doi.org/10.1108/TPM-03-2020$\underline{0024}$

Nurcahyani, N. M., \& Adnyani, I. G. A. D. (2016). Pengaruh Kompensasi dan Motivasi Terhadap Kinerja Karyawan Dengan Kepuasan Kerja Sebagai Variabel Intervening. Jurnal Manajemen Unud, Vol. 5, 500-532.

Pawirosumarto, S., Sarjana, P. K., \& Gunawan, R. (2017). The effect of work environment, leadership style, and organizational culture towards job satisfaction and its implication towards employee performance in Parador hotels and resorts, Indonesia. International Journal of Law and Management, 59(6), 1337-1358. https://doi.org/10.1108/IJLMA-10-2016-0085

Pham, H. (2016). The Impacts of Job Motivation and Job Satisfaction on Job Performance Among Employees of Retail Banking Sector in Vietnam. International Journal of Management Research and ..., 1, 1-27. https://papers.ssrn.com/sol3/papers.cfm?abstract_id=2859337

Pradhan, R. K., \& Jena, L. K. (2017). Employee Performance at Workplace: Conceptual Model and Empirical Validation. Business Perspectives and Research, 5(1), 69-85. https://doi.org/10.1177/2278533716671630 
Risqi, R. O., Ushada, M., \& Supartono, W. (2015). Analisis Pengaruh Kepuasan Kerja Terhadap Kinerja Karyawan Dengan Pendekatan Kansei Engineering Perusahaan XYZ. Agritech, 35(1), 78-87.

Robbins, S. P., \& Judge, T. A. (2015). Perilaku Organisasi (Edisi 16). Salemba Empat.

Rosita, S., \& Musnaini, D. M. F. (2020). Commitment, Satisfaction and Motivation in Improving Organizational Citizenship Behavior and Its Impact on Lecturer Performance in Higher Education. 3771-3782.

Shaukat, H., Ashraf, N., \& Ghafoor, S. (2015). Impact of Human Resource Management Practices on Employees Performance. 23(2), 329-338. https://doi.org/10.5829/ idosi.mejsr.2015.23.02.22117

Tabassum, U., Sherani, K., Wahid, B. A., \& Khan, I. (2016). The Relationship between Job Satisfaction and Job Performance among Employees: A Case of Commercial Banks in Punjab City, Pakistan. PM World Journal, Volume V(Issue VIII), 1-17.

Tellioğlu, H. (2010). Coordination of work: Towards a typology. ACM International Conference Proceeding Series, 471, 311-316. https://doi.org/10.1145/1839379.1839434

Tenney, E. R., Poole, J. M., \& Diener, E. (2016). Does positivity enhance work performance?: Why, when, and what we don't know. Research in Organizational Behavior, 36, 27-46. https://doi.org/10.1016/j.riob.2016.11.002

Vanagas, R., \& Stankevič, J. (2015). Impact of coordination for organization process. Intellectual Economics, 8(2), 112. https://doi.org/10.13165/ie-14-8-2-08

Warr, P., \& Nielsen, K. (2018). Wellbeing and work performance. Handbook of WellBeing, February, 1-22. https://www.sheffield.ac.uk/polopoly fs/1.740690!/file/

Zhou, J., Wang, Q., Tsai, S. B., Xue, Y., \& Dong, W. (2017). How to Evaluate the Job Satisfaction of Development Personnel. IEEE Transactions on Systems, Man, and Cybernetics:

Systems, 47(11), 2809-2816. https://doi.org/10.1109/TSMC.2016.2519860 